\title{
PETROGRAPHY, GEOCHEMISTRY AND RADIOACTIVITY OF ALKALINE A-TYPE GRANITES AND ASSOCIATED PEGMATITES FROM GABAL UM GURUF REGION, NORTH EASTERN DESERT, EGYPT
}

\author{
Amr Abdel Aty Abdel Hamid \\ Nuclear Materials Authority, P.O 530 Al Maadi, Cairo,Egypt
}

\begin{abstract}
The present study focuses on three granitic bodies from Gabal Um Guruf region in the North Eastern Desert of Egypt. They comprise Gabal El Resha fine-grained granite, Gabal Homret El Sawrhiya mediumgrained granite and Wadi El Misdar coarse-grained granite. They have nearly similar mineralogical compositions and could be classified as alkali feldspar granites. However, the presence and proportions of the accessory minerals show some variations among the three granitic bodies, causing observed changes in their trace element compositions. Geochemically, these granites exhibit pronounced A-type affinity and belong to the alkaline series. They have high concentrations of $\mathrm{SiO}_{2}$ and total alkalis, low abundances of $\mathrm{CaO}, \mathrm{MgO}$ and $\mathrm{TiO}_{2}$ and enrichment in some HFSE ( $\mathrm{Zr}, \mathrm{Y}$ and $\mathrm{U}$ ). The granitic bodies show similar REE patterns and spider diagrams with striking depletions in $\mathrm{Ba}, \mathrm{Sr}, \mathrm{P}, \mathrm{Eu}$, and Ti. The obtained geological, petrographical, and geochemical data of the studied granites suggest close genetic relationships and it is suggested that they were formed from single parent magma through its differentiation in post-orogenic environment. The radiometric investigation indicates that Gabal Homret Al Sawrhiya granite and its associated pegmatites have the highest levels of gamma-ray measurements in the study area. This granite shows similar mineralogical and geochemical features with U-bearing granite in Egypt. It is enriched in radioactive inclusions along with higher contents of zircon and fluorite, suggesting parallel enrichment of $F$ and HFSE, which extending toward the associated highly evolved pegmatites. Additionally, it displays various forms of post-magmatic hydrothermal alterations, especially along faults and shear zones. One radioactive anomaly was recorded in a pegmatite body in Gabal Homret El Sawrhiya granite. The pegmatite hosts U-Th, Zr and REE showings along the contact between the host granite and the pegmatite.
\end{abstract}

Keywords: Gabal Um Guruf; alkaline granites; A-type granites; radioactive pegmatites.

\section{INTRODUCTION}

The final phase of the Neoproterozoic Pan African orogeny ( $600-540 \mathrm{Ma})$ was dominated by emplacement of A-type characterized the region during the Phanerozoic (e.g.: Stern and Gottfried, 1986 and Jarrar et al., 1992). In granites, this stage marks the transition to intra-plate, alkaline magmatism which the vast crustal provinces of the Arabian-Nubian Shield three rock types are dominant among the A-type granites: metaluminous syenogranite, alkali-feldspar (mostly perthitic) granite and peralkaline granite (Bentor, 1985; El-Sayed et al. 2003; Jarrar et al. 2008; Eyal et al. 2010; Ali et al. 2012). The occurrences of alkaline A-type granites attract attention of many researchers, because they are indicators of definite geodynamic regimes, serve as an excellent illustration for magmatic differentiation, and also frequently bear complex rare-metal mineralization (Vladykin et al. 2016).

In the Eastern Desert of Egypt, the alkaline granites are of considerable importance as they host significant uranium mineralization and also form a suite of rare metal pegmatites (Cuney 2003). The younger granites from Gabal (G.) Um Guruf region have been studied by different authors (E.g.: Abu El Leil 1980; El Feky 1996; Abdel Hadi 2006). According to viewpoint of these authors these granites represent typical alkaline granites in this plutonic suite, of which are indicative of uranium deposition. This paper presents petrographical and geochemical data of the Late Neoproterozoic granites of G. Um Guruf region. Their petrogenesis and tectonic implications using the available geochemical data are then 


\begin{abstract}
Abdel Hamid, A. A.
discussed. Ground radiometric survey work is conducted over the concerned granites and the data are
\end{abstract}

evaluated to define the radioactive anomalies in this area.

\title{
GEOLOGICAL SETTING
}

The study region is located in the North Eastern Desert of Egypt, about $50 \mathrm{~km}$ southwest Hurghada City along the western coast of the Red Sea (Fig. 1a). It is delineated by latitudes $27^{\circ} 08^{\prime} 40^{\prime \prime}, 27^{\circ} 14^{\prime} 43^{\prime \prime} \mathrm{N}$ and longitudes $33^{\circ} 02^{\prime} 39^{\prime \prime}, 33^{\circ} 10^{\prime} 01^{\prime \prime} \mathrm{E}$, covering an area of about $136 \mathrm{~km}^{2}$. The investigated district is mainly occupied by Late Neoproterozoic granites and Dokhan volcanics as well as dikes and veins (Fig. 1b). Wadi (W.) alluvium deposits of Quaternary age are filling the main courses of the dry valleys in the area. The studied granites seem to form a part of composite granitic massif "named G. Abu Harba environs" that contains two granitic phases of biotite and perthitic leucogranites each of them has medium and coarsegrained granitic varieties (Abu El Leil, 1980; Roz, 2001 and Abdel Hamid. 2013).

Field observations indicated that the investigated granites comprise three granitic bodies; each body displays its own morphological characteristics and could be mapped independently. They contain G. El Resha fine-grained granite, G. Homret El Sawrhiya medium-grained granite and W. El Misdar coarsegrained granite.

G. El Resha fine-grained granite forms the outer peripheries of the studied massif. It is a dike-like intrusion of high relief elongated to N-S direction (Fig. 2a). The contact between this granite and G. Homret El Sawrhiya is sharp. It is hard, massive and displaying colors ranging from reddish pink to red. This body is well jointed and occasionally exhibits a well-developed closed vertical jointing pattern. G. El Resha is invaded by numerous acidic dikes of granophyre composition usually trending to the NE direction.

G. Homret El Sawrhiya medium-grained granite covers significant exposures of the study region (Fig. 1). It occupies an elliptical area in the northern and central parts of the mapped region. It shows sharp intrusive contacts with the Hammamat sedimentary rocks at the western peripheries but its contact with W. El Misdar granite is ranging from sharp to diffuse in character. It forms a conspicuous conical mountain of smooth sides and sharp peaks (Fig. $2 \mathrm{~b}$ ). The rocks forming this granite are hard and of pink to reddish pink in color. The granite body is characterized by extrusion of numerous dikes, veins and pegmatites. It has been affected by hydrothermal solutions along fractures and fault zones, which causing many wall-rock alteration features. The alteration features are manifested by hematitization, kaolinitization, silicification, fluoritization and chloritization as well as epidotization and the frequent presence of manganese dendrites.

G. Homret El Sawrhiya medium-grained granite covers significant exposures of the study region (Fig. 1). It occupies an elliptical area in the northern and central parts of the mapped region. It shows sharp intrusive contacts with the Hammamat sedimentary rocks at the western peripheries but its contact with W. El Misdar granite is ranging from sharp to diffuse in character. It forms a conspicuous conical mountain of smooth sides and sharp peaks (Fig. 2b). The rocks forming this granite are hard and of pink to reddish pink in color. The granite body is characterized by extrusion of numerous dikes, veins and pegmatites. It has been affected by hydrothermal solutions along fractures and fault zones, which causing many wall-rock alteration features. The alteration features are manifested by hematitization, kaolinitization, silicification, fluoritization and chloritization as well as epidotization and the frequent presence of manganese dendrites.

W. El Misdar coarse-grained granite is intruded through a restricted zone between Homret G. El Sawrhiya granite and G. Um Guruf volcanics. It occurs as semi-girdle shaped outcrops that extending along the southern parts of the mapped area. It forms high to moderate serrated ridges topped by sharp erosional peaks. This granite intrudes G. Um Guruf Dokhan volcanics with clear sharp intrusive contacts (Fig. 2c). It encloses large rafts and roof pendants of these volcanics. The rocks are sheared in some parts and have little resistant nature to weathering, which ranging in color from pale pink to faint brownish pink. W. El Misdar granite is intruded by acidic dikes as well as by quartz veins and pegmatite lenses. 
Petrography, geochemistry and radioactivity of alkaline A- type granites

Fig. 1: (a) Location map of the study area and (b) Geologic map showing the distribution of the granites from G. Um Guruf area, North Eastern Desert, Egypt (modified after Abdel Hadi 2006).
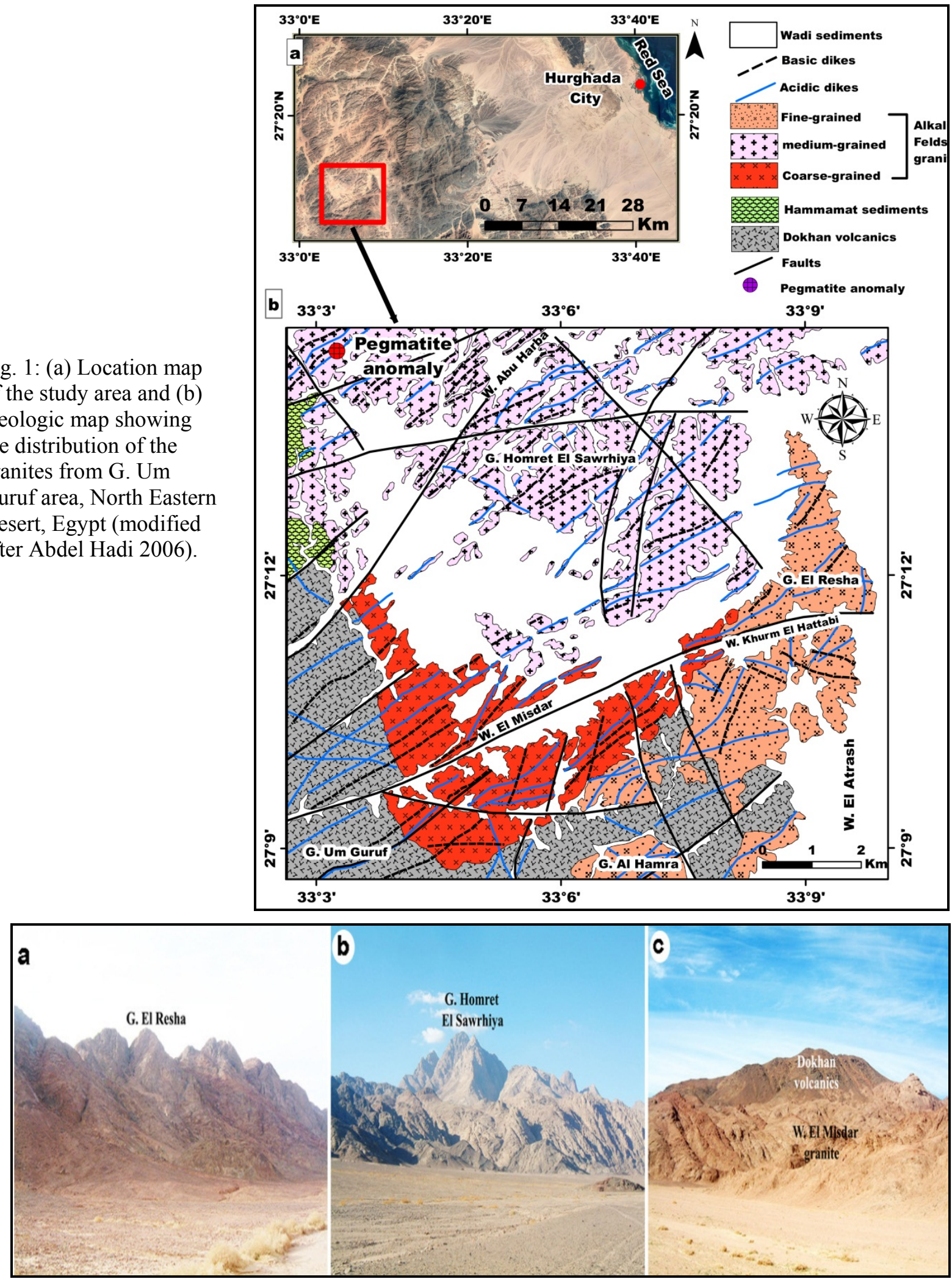

Fig. 2 (a) G. El Resha fine-grained granite forms elongated intrusion of high relief, (c) G. Homret El Sawrhiya medium-grained granite forms a conspicuous conical mountain of smooth sides and sharp peaks and (c) sharp contact between W. Al Misdar coarse-grained granite and G. Um Guruf Dokhan volcanics. 
Abdel Hamid, A. A.

\section{MATERIALS AND METHODS}

Forty samples representing the studied granites were collected from fresh outcrops over the study area. Thin sections were examined by transmitted and reflected light optical microscopy in order to characterize mineral textural relationships. In addition, two radioactive samples were collected from the radioactive pegmatites and prepared for mineralogical studies. Polished sections of these two samples were prepared then separating their contained accessory minerals by the standard heavy liquid method using bromoform (SG 2.89). Back scattered electron (BSE) imaging and energy dispersive spectroscopy (EDS) analyses were conducted over the polished section and the picked mineral grains with a Phillips XL 30 Scanning Electron microscope at the laboratory of the Nuclear Materials Authority of Egypt.

Whole rock chemical analyses were performed on eleven granitic fresh samples and two radioactive samples. Major and trace elements concentrations were determined using inductively coupled plasma mass spectrometry (ICP-MS) at the Acme laboratory, Vancouver, Canada.

\section{PETROGRAPHY OF THE STUDIED GRANITES}

Overall, the granites are leucocratic with hypidiomorphic granular texture. The major minerals are Kfeldspar and quartz with little plagioclase. Biotite is the main mafic mineral in studied granites. Iron oxides are the major accessory minerals besides variable abundances of zircon, titanite, rutile, apatite and fluorite. Accessories are mainly hosted in micas but also in K-feldspar and quartz. Alteration products are mainly sericite in the core of zoned plagioclase crystals. Turbidity of K-feldspar is extensively exhibited. An intergranular albite-rich plagioclase film is commonly developed between plagioclase and K-feldspar crystals, especially in Homret El Sawrhiya granite. Biotite is almost partially or totally replaced by chlorite and then coated by liberated Fe-oxides. Interstitial secondary muscovite is also present. The mineralogical composition of Homret El Sawrhiya granite is similar to that of the W. El Misdar granite. However, it has a relatively considerable amount of muscovite as well as lot minute radioactive inclusions, besides it possesses lesser biotite and higher quartz.

G. El Resha fine-grained granite is distinguished by its red color, smaller grain size and predominance of graphic texture. It consists of equant, anhedral perthite grains and quartz, with small amounts of plagioclase (Fig. 3a). Almost all K-feldspar crystals are characterized by dense brown turbid patch perthite. It is rich in the albite-component when compared to Homret El Sawrhiya and W. El Misdar granites. Quartz occurs as subhedral to anhedral crystals of variable sizes and shapes. It corrodes both the plagioclase and the perthite. The biotite flakes are altered to chlorite and sometimes to epidote (Fig. 3b). Zircon exists in little amount and mostly occurs as minute prisms with high relief and strong birefringence. It is significantly more equant and smaller in this granite.

In G. Homret El Sawrhiya medium-grained granite, K-feldspar is represented by orthoclase perthite and microcline perthite, whereas the latter is dominant. Quartz occurs as large subhedral crystals as well as anhedral fine-grained crystals occupying the interstitial spaces between perthite and plagioclase. Plagioclase is decreased relative to W. El Misdar granite, which exists as euhedral to subhedral prisms and tablets. Biotite encloses minute crystals of titanite, opaques, fluorite and zircon. The amount of muscovite is remarkably increased and becomes more abundance than biotite in this granite (Fig. 3c). Zircon is found as the most abundant accessory mineral in this granite. It occurs as euhedral to subhedral prismatic crystals. It appears as zoned crystals with clusters of inclusions of radioactive minerals and occasionally exhibits color zoning as well as metamictization (Fig. 3d). The amount of accessory fluorite in this granite is noticeably higher. Fluorite is crystallized interstitially together with micas and accessory minerals rich in HFSE such as zircon (Fig. 3e). These textural features suggest the parallel enrichment of F and HFSE in the residual magmas.

Wadi El Misdar coarse-grained granite is essentially composed of k-feldspar and quartz with subordinate amounts of plagioclase. The K-feldspar is essentially represented by both orthoclase perthite and microcline perthite; the latter is of less abundance. The perthite forms anhedral to subhedral crystals of 
Petrography, geochemistry and radioactivity of alkaline A- type granites

coarse-grained patchy type. Quartz, biotite and titanite are increased in abundances relative to G. El Resha granite (Fig. 3f). Zircon, iron oxides, apatite, fluorite, muscovite, epidote and chlorite are the most common accessory minerals in this granite.
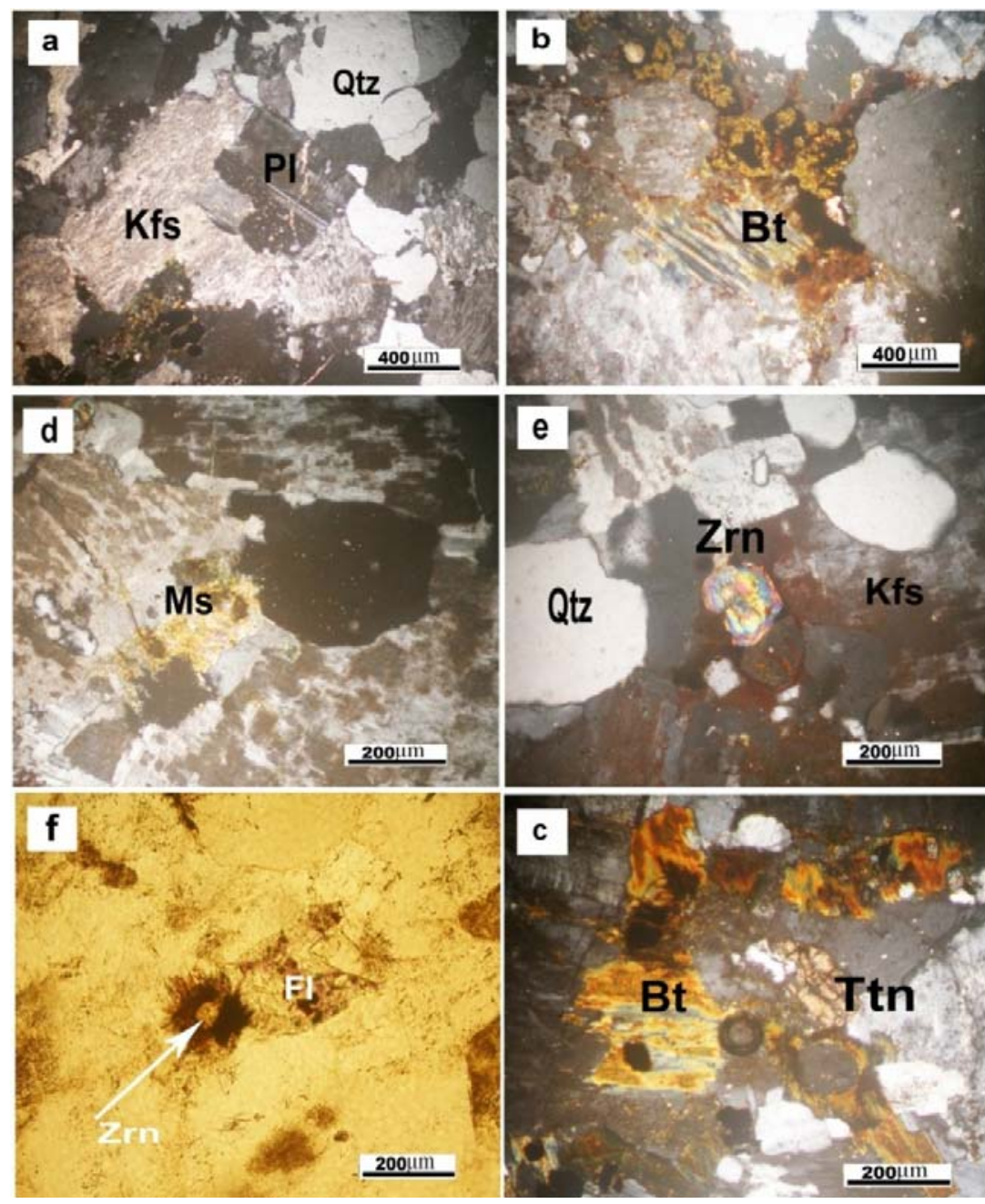

Fig. 3: Photomicrographs showing the composition of the studied granites (a) the essential minerals of G. El Resha granite, C. N., (b) chloritized biotite in G. El Resha granite, C. N., (c) muscovite increased in abundance in $\mathrm{G}$. Homret El Sawrhiya granite, C. N., (d) zircon as the main radioactive mineral in G. Homret El Sawrhiya granite, C. N., (e) fluorite crystallized interstitially together with zircon in G. Homret El Sawrhiya granite, P. L. and (f) marked amount of biotite and titanite specifically seen in W. El Misdar granite, C. N., abbreviation of minerals are from Kretz (1983), Kfs: K-feldspar, Pl: plagioclase, Qtz: Quartz, Bt: biotite, Zrn: zircon, Fl: fluorite, Ms: Muscovite.

\section{GEOCHEMISTRY OF THE STUDIED GRANITES}

\section{Major and trace elements characteristics}

Major, trace and rare earth element abundances together with some chemical parameters of the investigated granites were listed in Tables $(1,2)$. The mean values of the medium-grained G. Abu Harba Ubearing granite published by Abdel Hamid (2013) are given for comparison. In contrast, the major elements contents of the studied granites are close to those of G. Abu Harba granite, while the trace elements concentrations show some variations. Sr and $\mathrm{Ba}$ are much higher, while the elements $\mathrm{Zr}, \mathrm{Y}, \mathrm{Pb}, \mathrm{Zn}$ and $\mathrm{REE}$ are slightly enriched. On the other hand, $\mathrm{Rb}, \mathrm{Ga}, \mathrm{Nb}$, Th and $\mathrm{U}$ display lower values compared to those of G. Abu Harba granite. The studied granites can be classified using the cationic classification $R_{1}-R_{2}$ of De la Roche et al. (1980), whereas they entirely plot in the alkali granite field (Fig. 4).

The analyzed samples exhibit restricted range of higher $\mathrm{SiO}_{2}(76.15-77.43 \mathrm{wt} . \%)$ and alkali contents $\left(\mathrm{Na}_{2} \mathrm{O}+\mathrm{K}_{2} \mathrm{O}=8.57-9.39\right.$ wt.\%). The differentiation index (DI) ranges from 92 to 96.2 , implying a highly differentiated granite affinity (Table 1). On $\mathrm{SiO}_{2}$ vs. $\mathrm{K}_{2} \mathrm{O}$ diagram, they precisely plot within the high-K calc-alkaline field (Fig. 5a). The alkaline affinity is also indicated by the diagram adopted by Sylvester (1989), whereas most of the analyzed samples are lie between the alkaline and highly fractionated calcalkaline fields (Fig. 5b). The studied granites have agpaitic index (AI) $>1$ (ranging between 1.09 and 1.33), 
Abdel Hamid, A. A.

and are thus classified as peralkaline granites, according to Liégeois and Black (1987). They have low $\mathrm{Al}_{2} \mathrm{O}_{3}$ contents ranging from 9.46 to $11.66 \mathrm{wt}$ \% $\%$ and when plotted in $\mathrm{A} / \mathrm{NK}\left(\mathrm{molar}_{2} \mathrm{Al}_{3} / \mathrm{Na}_{2} \mathrm{O}+\mathrm{K}_{2} \mathrm{O}\right)$ vs. $\mathrm{A} / \mathrm{CNK}$ (molar $\mathrm{Al}_{2} \mathrm{O}_{3} / \mathrm{CaO}+\mathrm{Na}_{2} \mathrm{O}+\mathrm{K}_{2} \mathrm{O}$ ) diagram (Maniar and Piccoli, 1989), they fall in the peralkaline field (Fig. 5c). Based on the classification of Frost et al. (2001), most of the studied samples are ferroan (Fig. 6a), and they straddle the boundary between calc-alkalic and alkalic-calcic fields (Fig. 6b).

Table 1 Major oxides (wt. \%) and trace elements (ppm) analysis with some parameters and ratios of the studied granites.

\begin{tabular}{|c|c|c|c|c|c|c|c|c|c|c|c|c|}
\hline & \multirow{2}{*}{$\begin{array}{l}\text { Av. Alkali } \\
\text { feldspar } \\
\text { granite G. } \\
\text { Abu Harba } \\
\text { (Abdel } \\
\text { Hamid } \\
\text { 2013) }\end{array}$} & \multicolumn{3}{|c|}{$\begin{array}{l}\text { G. El Resha fine-grained } \\
\text { granite }\end{array}$} & \multicolumn{4}{|c|}{$\begin{array}{l}\text { G. Homret El Sawrhiya medium- } \\
\text { grained granite }\end{array}$} & \multicolumn{4}{|c|}{ W. El Misdar coarse-grained granite } \\
\hline & & $\mathrm{R}-1$ & $\mathrm{R}-2$ & $\mathrm{R}-3$ & S-4 & S-5 & S-6 & S-7 & M-8 & M-9 & M-10 & M-11 \\
\hline \multicolumn{13}{|c|}{ Major elements (Wt.\%) } \\
\hline $\mathrm{SiO}_{2}$ & 76.79 & 76.15 & 76.28 & 76.63 & 76.77 & 77.29 & 77.43 & 76.36 & 76.80 & 76.56 & 77.31 & 77.40 \\
\hline $\mathrm{TiO}_{2}$ & 0.13 & 0.15 & 0.18 & 0.12 & 0.12 & 0.13 & 0.16 & 0.11 & 0.26 & 0.21 & 0.14 & 0.12 \\
\hline $\mathrm{Al}_{2} \mathrm{O}_{3}$ & 12.05 & 11.66 & 11.52 & 11.24 & 11.46 & 11.08 & 10.95 & 11.29 & 10.18 & 10.62 & 10.33 & 10.88 \\
\hline $\mathrm{Fe}_{2} \mathrm{O}_{3}$ & 0.79 & 0.92 & 1.23 & 1.06 & 0.74 & 0.89 & 1.03 & 1.32 & 1.36 & 1.06 & 1.12 & 0.69 \\
\hline $\mathrm{FeO}$ & 0.24 & 0.21 & 0.36 & 0.38 & 0.18 & 0.23 & 0.24 & 0.35 & 0.31 & 0.22 & 0.25 & 0.15 \\
\hline $\mathrm{MnO}$ & 0.05 & 0.04 & 0.12 & 0.08 & 0.03 & 0.04 & 0.03 & 0.04 & 0.07 & 0.06 & 0.02 & 0.05 \\
\hline $\mathrm{MgO}$ & 0.10 & 0.23 & 0.27 & 0.28 & 0.08 & 0.05 & 0.07 & 0.13 & 0.25 & 0.22 & 0.08 & 0.07 \\
\hline $\mathrm{CaO}$ & 0.38 & 0.50 & 0.43 & 0.41 & 0.27 & 0.46 & 0.39 & 0.24 & 0.46 & 0.53 & 0.27 & 0.28 \\
\hline $\mathrm{Na}_{2} \mathrm{O}$ & 4.14 & 4.34 & 4.33 & 4.25 & 4.40 & 4.37 & 4.23 & 4.28 & 4.27 & 4.45 & 4.26 & 4.64 \\
\hline $\mathrm{K}_{2} \mathrm{O}$ & 4.39 & 4.65 & 4.39 & 4.32 & 4.34 & 4.25 & 4.47 & 4.65 & 4.66 & 4.87 & 4.82 & 4.74 \\
\hline $\mathrm{P}_{2} \mathrm{O}_{5}$ & -- & 0.02 & 0.03 & 0.02 & 0.01 & 0.02 & 0.01 & 0.01 & 0.03 & 0.03 & 0.01 & 0.01 \\
\hline L.O.I & & 1.09 & 0.82 & 1.17 & 1.58 & 1.16 & 0.96 & 1.18 & 1.32 & 1.16 & 1.35 & 0.96 \\
\hline D. I & 97.06 & 94.8 & 94.0 & 94.3 & 96.2 & 95.1 & 94.8 & 94.2 & 92.0 & 92.7 & 93.5 & 94.6 \\
\hline \multicolumn{13}{|c|}{ Trace elements (ppm) } \\
\hline $\mathrm{Ba}$ & 73.4 & 589 & 638 & 489 & 88 & 130 & 179 & 118 & 468 & 466 & 253 & 176 \\
\hline $\mathrm{Rb}$ & 273.4 & 126 & 109 & 121 & 72 & 115 & 138 & 159 & 112 & 113 & 113 & 125 \\
\hline $\mathrm{Sr}$ & 24.1 & 73 & 100 & 85 & 18 & 28 & 41 & 23 & 67 & 67 & 24 & 19 \\
\hline Cs & 3.53 & 1.6 & 0.9 & 1.4 & 0.7 & 1.5 & 2.7 & 3.5 & 1.9 & 1.9 & 1.9 & 2.8 \\
\hline $\mathrm{Ga}$ & 20.9 & 16.4 & 16.0 & 16.3 & 19.1 & 18.3 & 18.6 & 21.4 & 17.6 & 17.3 & 17.3 & 17.1 \\
\hline $\mathrm{Ta}$ & 2.4 & 1.2 & 1.4 & 1.2 & 1.0 & 1.2 & 1.4 & 1.3 & 1.5 & 1.1 & 1.1 & 1.3 \\
\hline $\mathrm{Nb}$ & 42.3 & 12.4 & 14.9 & 12.2 & 11.4 & 15.2 & 12.9 & 13.2 & 18.3 & 13.8 & 12.7 & 16.4 \\
\hline Hf & 6.69 & 4.5 & 5.4 & 5.2 & 5.4 & 6.1 & 5.2 & 6.9 & 4.6 & 4.6 & 4.3 & 4.5 \\
\hline $\mathrm{Zr}$ & 117 & 126 & 144 & 137 & 132 & 141 & 153 & 121 & 129 & 126 & 127 & 108 \\
\hline $\mathrm{Y}$ & 14.8 & 24.6 & 28.5 & 26.1 & 37.3 & 31.7 & 29.2 & 25.6 & 35.9 & 28.5 & 26.5 & 29.2 \\
\hline $\mathrm{Ni}$ & -- & 0.8 & 6.0 & 2.8 & 3.4 & 2.1 & 4.2 & 3.0 & 4.3 & 2.7 & 2.9 & 2.4 \\
\hline $\mathrm{Cr}$ & 12.5 & 9 & 48 & 6 & 7 & 9 & 9 & 10 & 5 & 6 & 5 & 4 \\
\hline $\mathrm{Co}$ & -- & 1.0 & 1.7 & 1.4 & 0.9 & 1.3 & 2.0 & 1.8 & 2.2 & 1.3 & 0.5 & 0.5 \\
\hline $\mathrm{V}$ & -- & 6 & 7 & 8 & 4 & 9 & 6 & 5 & 12 & 8 & 4 & 5 \\
\hline $\mathrm{Cu}$ & -- & 10 & 21 & 19 & 37 & 18 & 31 & 14 & 70 & 17 & 22 & 36 \\
\hline $\mathrm{Pb}$ & 20.0 & 48 & 64 & 57 & 128 & 70 & 85 & 77 & 206 & 53 & 65 & 93 \\
\hline $\mathrm{Zn}$ & 41.4 & 110 & 131 & 160 & 284 & 160 & 183 & 211 & 713 & 184 & 139 & 333 \\
\hline $\mathrm{Th}$ & 30.45 & 14.7 & 21.2 & 15.3 & 15.3 & 14.7 & 23.5 & 18.6 & 15.4 & 11.2 & 13.9 & 12.6 \\
\hline $\mathrm{U}$ & 12.31 & 11.3 & 16.4 & 12.8 & 21.6 & 9.9 & 13.8 & 7.4 & 35.7 & 8.9 & 14 & 18.5 \\
\hline $\mathrm{Th} / \mathrm{U}$ & 2.75 & 1.30 & 1.29 & 1.20 & 0.71 & 1.49 & 1.70 & 2.51 & 0.43 & 1.26 & 0.99 & 0.68 \\
\hline
\end{tabular}

The analyzed samples share all features common to A-type granites in terms of trace element geochemistry. They are typically high in $\mathrm{Ga}, \mathrm{Zn}, \mathrm{Zr}, \mathrm{Nb}$ and $\mathrm{Y}$, and low in $\mathrm{Sr}$, with some variation in $\mathrm{Ba}$ and $\mathrm{Rb}$ (Collins et al. 1982; Whalen et al. 1987a). The average 10,000 Ga/Al ratios in these rocks are 2.623.81, with an average of 3.11, little lower than the global average 3.75 for A-type granites (Whalen et al. 1987a). In the discrimination diagrams of $\mathrm{Na}_{2} \mathrm{O}+\mathrm{K}_{2} \mathrm{O}, \mathrm{Zr}$ and $\mathrm{Nb}$ vs. 10,000 Ga/Al (Fig. 7a-c), they plot in the A-type granite field (Whalen et al. 1987a). Furthermore, in the $\left(\mathrm{K}_{2} \mathrm{O}+\mathrm{Na}_{2} \mathrm{O}\right) / \mathrm{CaO}$ vs. 
Petrography, geochemistry and radioactivity of alkaline A- type granites

$(\mathrm{Zr}+\mathrm{Nb}+\mathrm{Y}+\mathrm{Ce})$ diagram, they fall in the fields of fractionated granite and A-type granites (Fig. 7d). It is worth to mention that the highly fractionated felsic I- and S-type granites have Ga/Al ratios and some major oxides and trace elements values, which overlap with those of the typical A-type granites (Whalen et al. 1987a). This is also confirmed by the classification scheme of Frost et al. (2001) using the diagram of $\mathrm{FeOt} /(\mathrm{FeOt}+\mathrm{MgO})$ vs. $\mathrm{SiO}_{2}$. In the spider diagram, the studied granites show the characteristic negative anomalies in Ba, Ta, Sr, P, Eu and Ti (Fig. 8a).

Table 2 Rare earth element concentrations (ppm) of the granites from G. Um Guruf area.

\begin{tabular}{|c|c|c|c|c|c|c|c|c|c|c|c|c|}
\hline & $\begin{array}{c}\text { Av. Alkali } \\
\text { feldspar } \\
\text { granite of G. } \\
\text { Abu Harba } \\
\text { (Abdel } \\
\text { Hamid 2013) }\end{array}$ & \multicolumn{2}{|c|}{$\begin{array}{c}\text { G. El Resha fine- } \\
\text { grained granite }\end{array}$} & \multicolumn{4}{|c|}{$\begin{array}{c}\text { G. Homret El Sawrhiya } \\
\text { medium-graned granite }\end{array}$} & \multicolumn{3}{|c|}{ W. El Misdar coarse-grained } \\
granite
\end{tabular}

Fig. 4: Chemical classification diagram R1-R2 (De La Roche et al.; 1980).

Symbols, $\bullet$ : G. El Resha granite finegrained granite, $\bullet$ : G. Homret El Sawrhiya medium-grained granite, + : W. El Misdar coarse-grained granite.

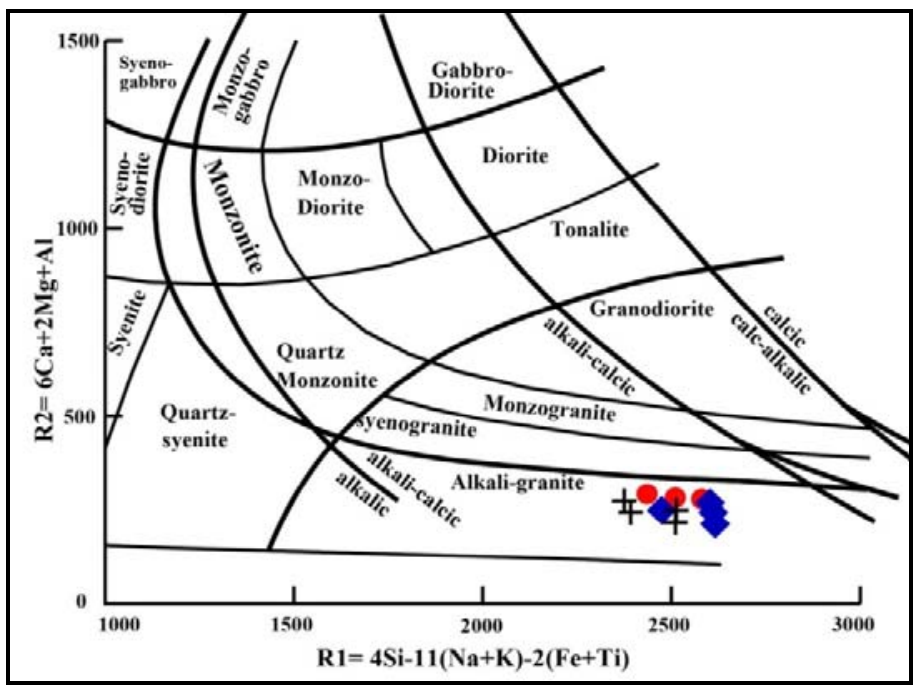

The REE contents for the studied granites vary from 89.28 to $204.87 \mathrm{ppm}$ (Table 2), lower than the average REE content (250ppm) of granite (Herrmann 1970). Chondrite-normalized REE pattern (Sun and McDonough 1989) indicates that the LREE are more enriched than the HREE, with deep Eu minimum (Fig. 8b). The medium-grained granite of G. Homret El Sawrhiya, however, differs in the depth of anomalies of some elements. The striking depletions in $\mathrm{Ba}, \mathrm{Sr}, \mathrm{P}, \mathrm{Eu}$, and Ti in REE patterns and spider diagrams are also common features of A-types granites (Collins et al., 1982; Whalen et al., 1987a; Bonin, 2007). 
Abdel Hamid, A. A.

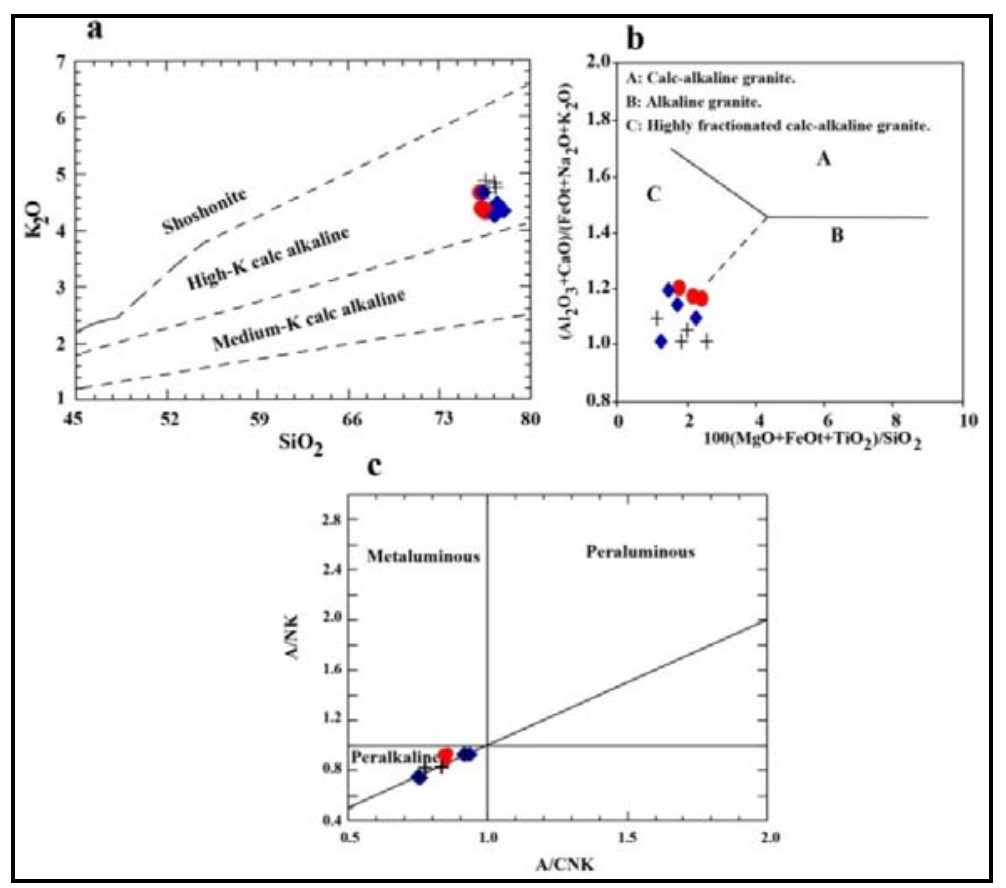

Fig. 5: (a) $\mathrm{K}_{2} \mathrm{O}$ vs. $\mathrm{SiO}_{2}$ diagram with field after Ewart (1982), (b) major element classification diagram after Sylvester (1989) and (c) $\mathrm{A} / \mathrm{CNK}$ versus $\mathrm{A} / \mathrm{NK}$ classification diagram after Maniar and Piccoli (1989) for the studied granites. Symbols are the same as in Fig. 4.
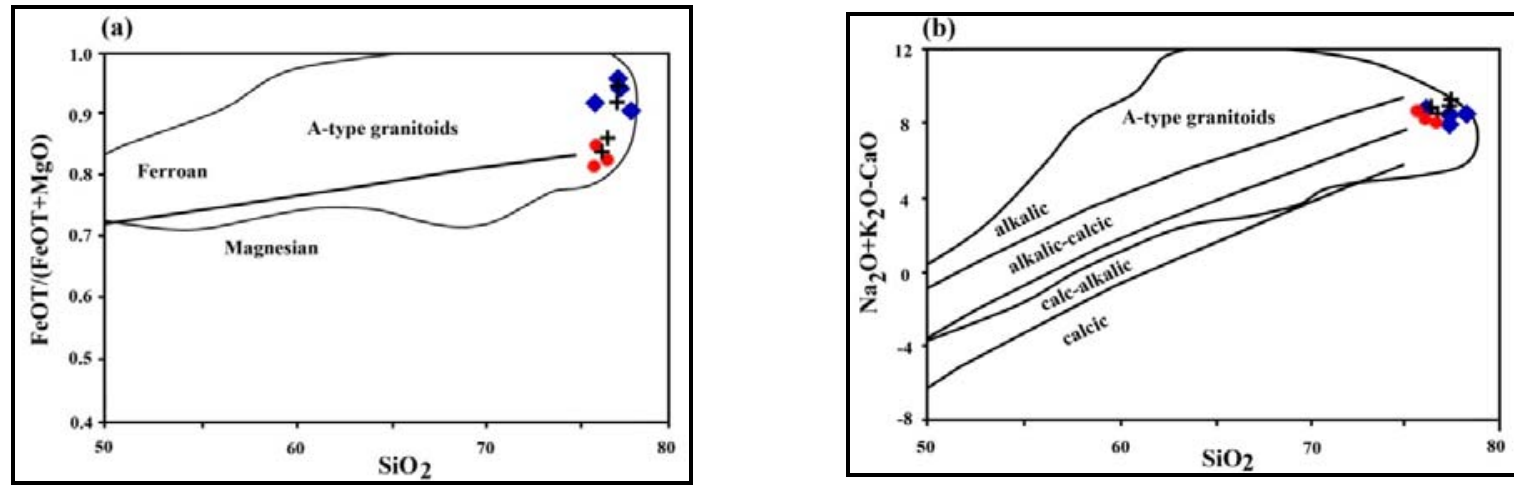

Fig. 6: (a) $\mathrm{SiO}_{2}$ versus $\mathrm{FeOt} /(\mathrm{FeOt}+\mathrm{MgO})$ and (b) $\mathrm{Na}_{2} \mathrm{O}+\mathrm{K}_{2} \mathrm{O}-\mathrm{CaO}$ discrimination diagrams for the studied granites (after Frost et al. 2001). Symbols are the same as in Fig 4.

\section{Tectonic setting}

A-type granites can be formed in both post-orogenic and anorogenic settings (Whalen et al. 1987a, 1996; Sylvester 1989; Bonin 1990; Eby 1990, 1992; Nedele et al. 1995; Pitcher 1997; Grebennikov 2014).

Eby (1992) subdivided A-type granites into $A_{1}$ and $A_{2}$ groups. $A_{1}$ group is related to sources generated by fractional crystallization like OIB (anorogenic setting); while $\mathrm{A}_{2}$ group is related to sources originally formed by partial melting of lower crust through subduction or continent-continent collision (post-orogenic setting).Using the $\mathrm{Nb}-\mathrm{Y}-3 \mathrm{Ga}$ ternary plot and $\mathrm{Rb} / \mathrm{Nb}-\mathrm{Y} / \mathrm{Nb}$ geochemical discriminant diagram of Eby (1992), the studied granites are exclusively plot into the $A_{2}$ group (Fig. 9 a,b), suggesting a post-orogenic tectonic setting. The studied granites plot in the field of the post-collisional tectonic setting delineated by Pearce (1996) and A-type granites in the field of Whalen et al. (1987a) on Rb vs. (Y $+\mathrm{Nb}$ ) discrimination diagram (Fig. 10a). In addition, all samples entirely fall in the field of A-type granites related to the ANS defined by Stern and Gottfried (1989) and within-plate setting on Nb vs. Y diagram (Fig. 10b). Also, the high contents of $\mathrm{FeOt}, \mathrm{K}_{2} \mathrm{O}, \mathrm{Rb}, \mathrm{Zr}$, Y, and HREE and low Sr contents along with flat HREE patterns and negative Eu anomalies in the studied granites also indicate a post-collisional nature (Rogers and Greenberg 1990). 
Petrography, geochemistry and radioactivity of alkaline A- type granites

Fig. 7: (a), (b), (c) and (d) A-type discrimination diagrams of Whalen et al. (1987a) for the studied granites. I, S and M (OGT): unfractionated I-, S- and Mtype granites, FG: fractionated I-type granites. Symbols are the same as in Fig. 4
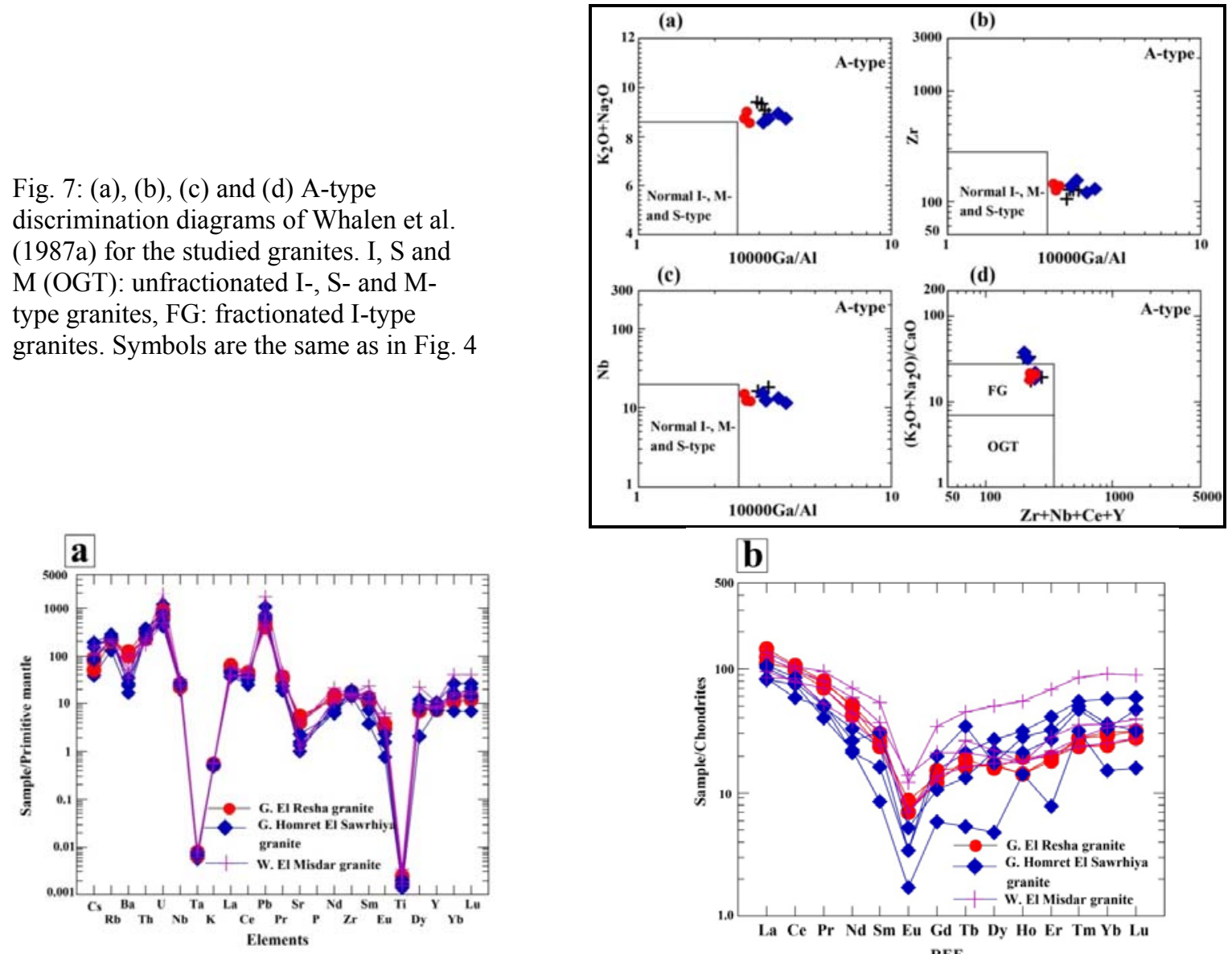

b

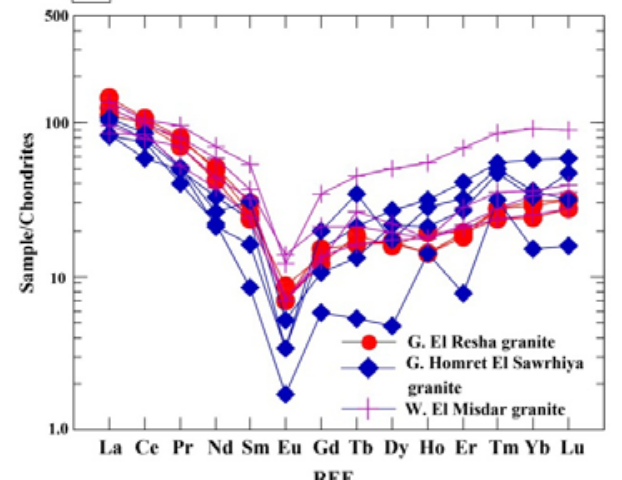

Fig. 8: (a) Primitive mantle normalized trace element and (b) chondrite-normalized REE patterns for the studied granites. The chondrite and PM values are from Sun and McDonough (1989).
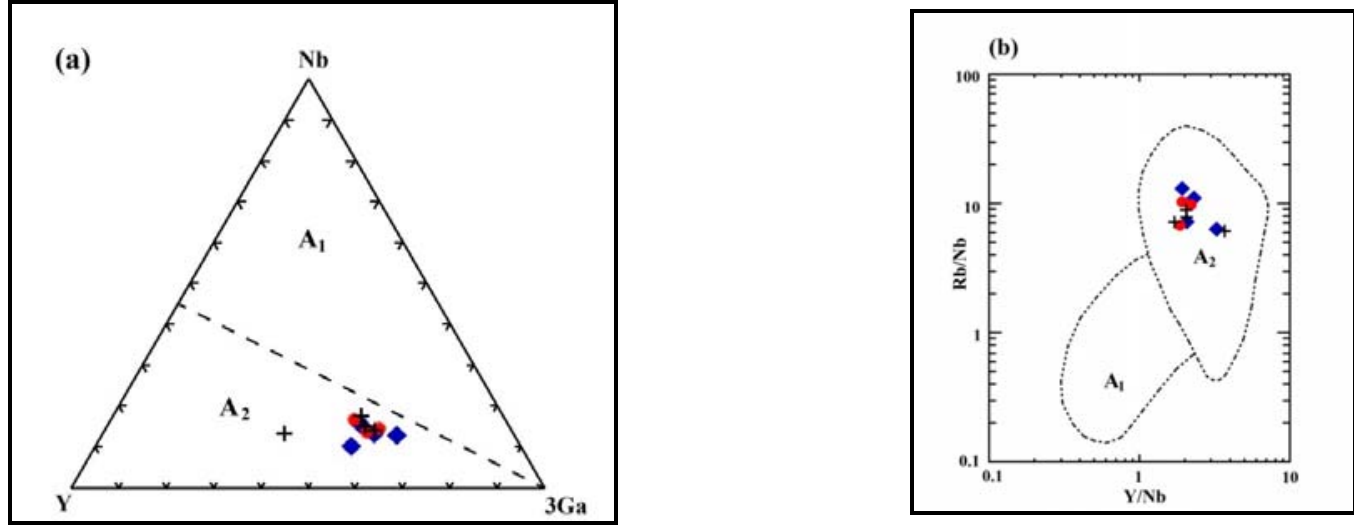

Fig. 9: (a) $\mathrm{Nb}-\mathrm{Y}-3 \mathrm{Ga}$ ternary diagram and (b) $\mathrm{Y} / \mathrm{Nb}$ versus $\mathrm{Rb} / \mathrm{Nb}$ discrimination diagram of the studied granites (after Eby 1992). $\mathrm{A}_{1}$ : anorogenic A-type granites, $\mathrm{A}_{2}$ : post-collisional A-type granites. Symbols are the same as in Fig. 4.

\section{RADIOACTIVITY}

Radiometric prospection using a hand held scintillometer (model RS-230) over the study area enabled the identification of $U$ anomalies over the studied granites. The background levels of the gamma intensities measured over the granitic exposures indicate that Homret El Sawrhiya granite possesses the highest measurements (310-360cps), followed by W. El Misdar granite (220-300 cps), while G. El Resha granite has the lowest values (170-240cps). G. Homret El Sawrhiya granite appears to be the more differentiated 
Abdel Hamid, A. A.

and volatile-rich unit. In particular, it has experienced various forms of alterations such as hematitization, albitization, silica dissolution, kaolinitization and chloritization. Moreover, numerous pegmatites, quartz veins and aplites are specifically widespread in this granite body. The relative abundances of these and bodies in the alkaline granites are indicative of increasing radioactivity. The overall field and mineralogical observations as well as the geochemical studies indicate that this granite display high level of uranium potential. Uranium can be fixed in its bearing accessory minerals in the highly evolved pegmatites or remobilized by the hydrothermal solutions to form secondary ore in its host Homret El Sawrhiya granite.
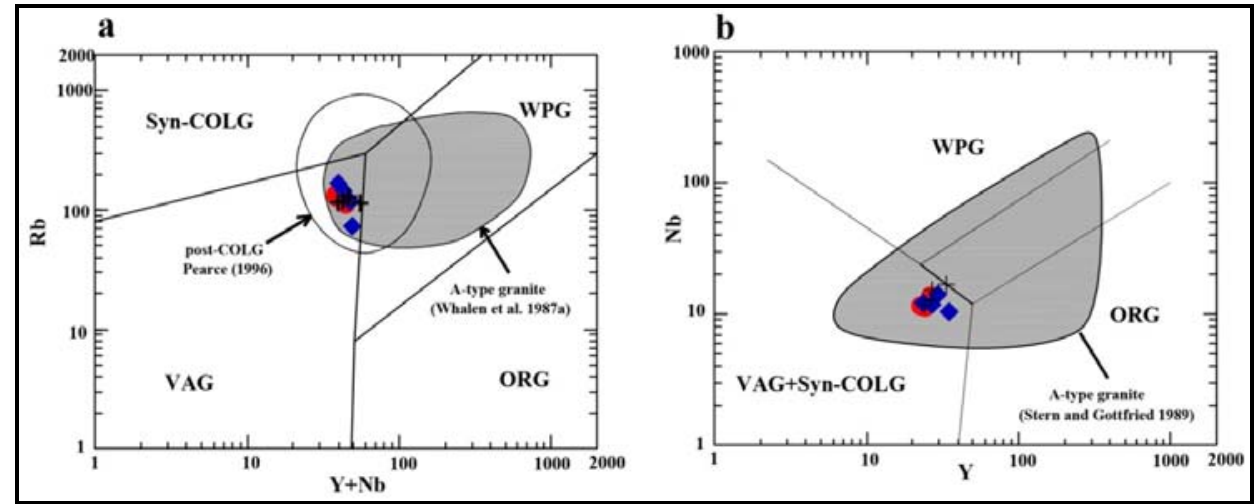

Fig. 10: Tectonic discrimination diagrams for the studied granites after Pearce et al. (1984), (a) Rb vs. (Y+ $\mathrm{Nb}$ ) diagram with post-collisional field after Pearce (1996) and A-type granite field after Whalen et al. (1987a) and (b) Nb vs. Y diagram with field of A-type granite after Stern and Gottfried (1989), for the studied granites. WPG: Within Plate Granitoids, COLG: Collision Granitoids, ORG: Orogenic Related Granitoids and VAG: Volcanic Arc Granitoids. Symbols are the same as in Fig. 4

\section{Radioactive anomaly}

The radioactive anomaly is recorded in a pegmatite body hosted by G. Homret El Sawrhiya granite, which locates at the northwestern parts of the mapped area (Fig. 1). Very high radiometric values, up to $12000 \mathrm{cps}$ were recorded in the feldspar-rich outer zone of this pegmatite. The pegmatite body is semicircular in shape with about $25 \mathrm{~m}$ width and $30 \mathrm{~m}$ long nearly oriented to the NW direction. It has a simple zoning structure with feldspar-rich outer zone and inner quartz core. The thickness of outer zone is about $5 \mathrm{~m}$, which suffered from strong silicification displayed by quartz veins and veinlets. The radioactive spots occur in the feldspar-rich zone (Fig. 11a). The samples are collected from the highest radioactive zones using the gamma-ray scintillometer (Fig. 11b). Two representative samples were selected for trace and rare earth elements analysis. They show highest concentrations in the elements $\mathrm{Nb}, \mathrm{Ta}, \mathrm{Hf}, \mathrm{Zr}, \mathrm{Y}, \mathrm{Th}, \mathrm{U}$ and total REE (Table 3).

Mineralogical studies of the accessory minerals separated from the two radioactive pegmatite samples and their corresponding polished thin sections reveal the extreme abundance of zircon that forming the major Zr-U-Th-REE-bearing mineral in this radioactive pegmatite. ESEM image and EDS spectrum of zircon grains are illustrated in Figure (12a). Thorite is recorded and represent the main Th-bearing mineral in the studied samples (Fig. 12b), whereas fergusonite-(Y) and monazite-(La) represent are the main carriers of REE (Fig. 12 c,d).

The U contents along the studied granites are varying between 7.4 and $35.7 \mathrm{ppm}$, which classify these rocks as uraniferous granite, much higher than that in typical granite (3.2 ppm, Flanagan 1976). On the other hand, Th also displays higher concentrations ranging from 11.2 to $23.5 \mathrm{ppm}$. The $\mathrm{Th} / \mathrm{U}$ ratios are varying between 0.43 and 2.51, which are lower than that reported in the literature (3.8) for granitic rocks (Taylor and Mclennan 1985; Van Schmuss 1995). Such lower ratios suggest U mobilization in the system leading to either selective enrichment or depletion. Figure (13) demonstrates that $U$ has undergone slight mobilization, especially in W. El Misdar granite assuming local redistribution of $U$ as the result of weathering effect on its coarse crystals (e.g. sample no. M-8; Table 1). In contrast, G. El Resha and G. 
Petrography, geochemistry and radioactivity of alkaline A- type granites

Homret El Sawrhiya granites show higher $\mathrm{Th} / \mathrm{U}$ ratios, which suggesting Th enrichment and U loss. The radioactive pegmatite samples are enriched in Th $(2067,3655 \mathrm{ppm})$ and $\mathrm{U}(189,316 \mathrm{ppm})$ whereas $\mathrm{Th} / \mathrm{U}$ ratios are much higher than those of the host G. Homret El Sawrhiya granite (Table 3).

Fig. 11: a) the radioactive anomalies occur in the feldsparrich outer zone of the pegmatite and $b$ ) gamma-ray scintillometer (model RS-230) is used for collecting the mineralized samples.
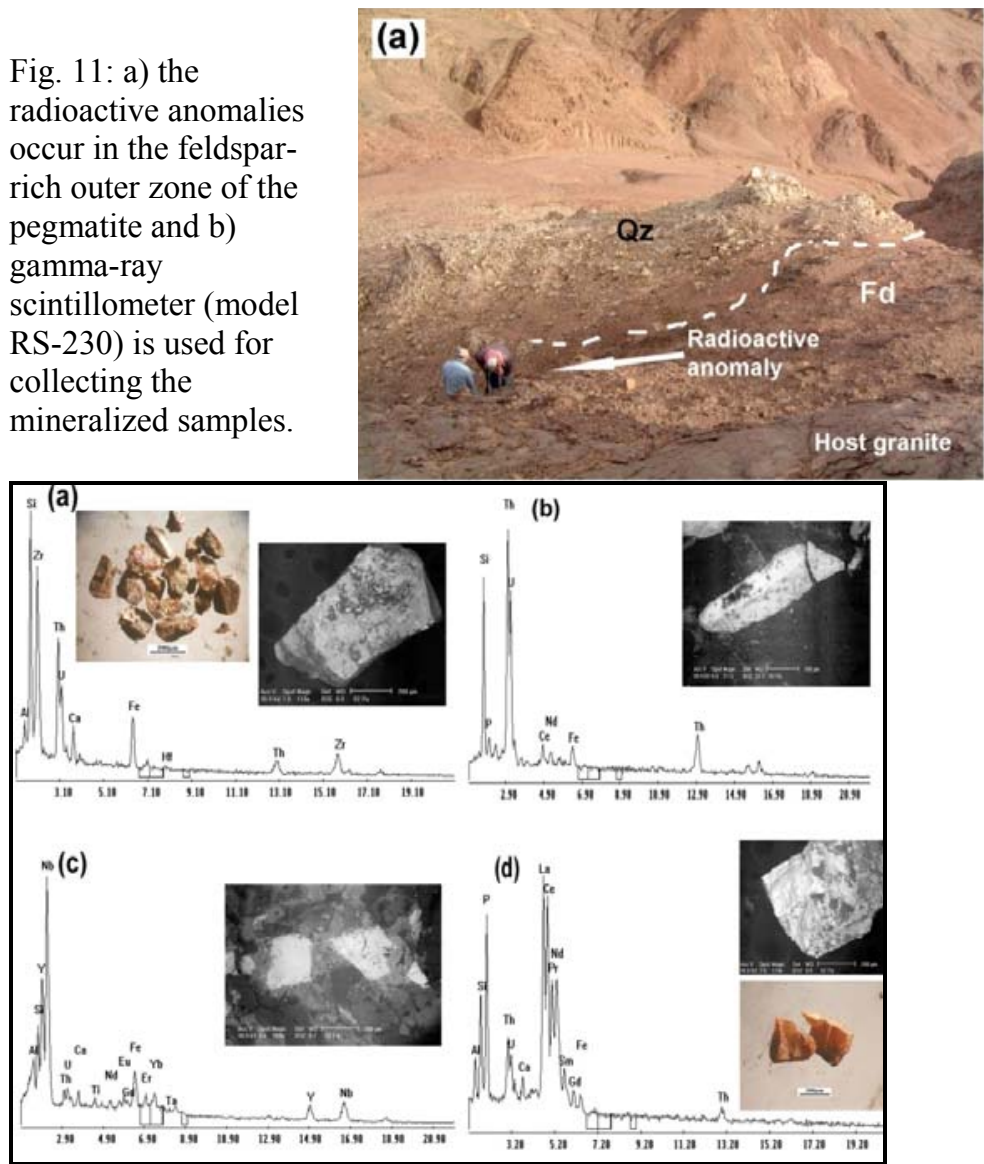

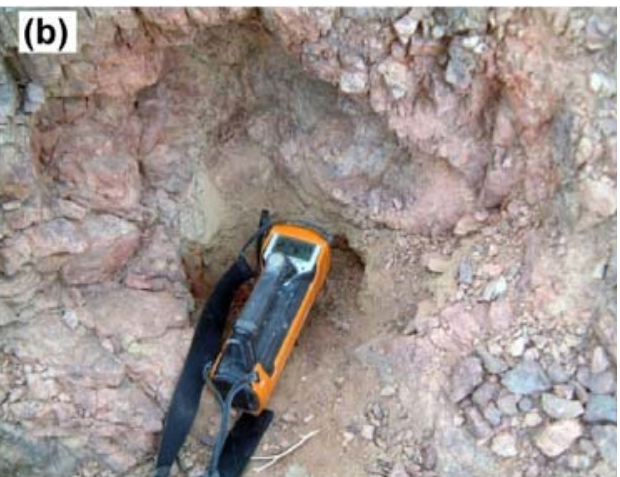

Fig. 12: Microphotographs illustrate the accessory phases from the radioactive pegmatite, (a) mineral grains (binocular microscope), ESEM image and EDS spectrum of zircon, (b) ESEM image and EDS spectrum of thorite from the polished sections, (c) ESEM image and EDS spectrum of fergusonite-

(Y) from polished thin section and

(d) mineral grains (binocular microscope), ESEM image and EDS spectrum of monazite-(La).

\section{Uranium and thorium distribution}

Although the three granitic bodies have obviously higher $U$ contents (more than the Clarke value 3$4 \mathrm{ppm}$ ), the high $U$ contents in the host rocks are not the main factor controlling the intensity of uranium mineralization. It was determined by the degree of uranium mobilization. Hydrothermal activity remobilizes fixed $U$ into fluid phase and eventually transports it to favorable sites where ore precipitation is then accompanied by intense alteration processes (Zhang et al. 2006).

Fig. 13 U-Th diagram for the studied granites and radioactive pegmatite.

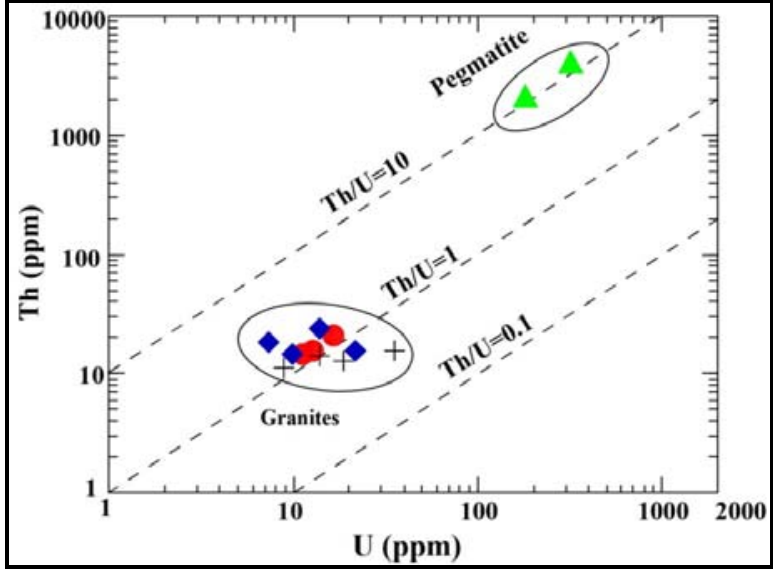


Abdel Hamid, A. A.

Table 3 Selective trace- and rare earth elements concentrations of two radioactive pegmatite samples.

\begin{tabular}{|c|c|c|}
\hline Elements & Sample 1 & Sample 2 \\
\hline \multicolumn{3}{|c|}{ Trace elements (ppm) } \\
\hline $\mathrm{Ta}$ & 84 & 44 \\
\hline $\mathrm{Nb}$ & 1941 & 666 \\
\hline $\mathrm{Hf}$ & 485 & 296 \\
\hline $\mathrm{Zr}$ & $>2000$ & $>2000$ \\
\hline $\bar{Y}$ & 820 & 323 \\
\hline $\mathrm{Pb}$ & 605 & 166 \\
\hline $\mathrm{Zn}$ & 227 & 136 \\
\hline Th & 3655 & 2067 \\
\hline $\mathrm{U}$ & 316 & 189 \\
\hline $\mathrm{Th} / \mathrm{U}$ & 11.6 & 10.9 \\
\hline \multicolumn{3}{|c|}{ Rare earth elements (ppm) } \\
\hline $\mathrm{La}$ & 1862 & 1256 \\
\hline $\mathrm{Ce}$ & 1982 & 1349 \\
\hline $\operatorname{Pr}$ & 108 & 81 \\
\hline $\mathrm{Nd}$ & 231 & 170 \\
\hline $\mathrm{Sm}$ & 27 & 18 \\
\hline $\mathrm{Eu}$ & 2.4 & 1.2 \\
\hline $\mathrm{Gd}$ & 34 & 17 \\
\hline $\mathrm{Tb}$ & 7 & 3 \\
\hline Dy & 68 & 32 \\
\hline Ho & 24 & 11 \\
\hline Er & 114 & 50 \\
\hline $\mathrm{Tm}$ & 28 & 12 \\
\hline $\mathrm{Yb}$ & 265 & 115 \\
\hline $\mathrm{Lu}$ & 56 & 24 \\
\hline ¿REE & 4808 & 3140 \\
\hline
\end{tabular}

The Late Neoproterezoic younger granites from G. Um Guruf suite, North Eastern Desert of Egypt are studied in details based on their corresponding petrography, geochemistry and radioactivity, the following are the conclusions:

1. The studied granites are represented by G. El Resha fine-grained granite, G. Homret El Sawrhiya medium-grained granite and W. El Misdar coarse-grained granite. The three granitic bodies seem to form one pluton, whereas the fine-grained granite makes up the outer peripheries of the pluton, the coarse-grained granite occupies the middle parts and the medium-grained granite constitutes the inner parts and occupying the bulk of the massif. The mineralogical compositions of the three granitic bodies are nearly similar with noticeable changes in the distribution of their accessory minerals.

2. The investigated granites are classified as alkali feldspar granites and their chemical features are characteristic of post-orogenic alkaline A-type granites. They are enriched in $\mathrm{SiO}_{2}$, total alkalis and HFSE, depleted in $\mathrm{Ba}, \mathrm{Sr}, \mathrm{P}, \mathrm{Eu}$ and $\mathrm{Ti}$ and have $\mathrm{Y} / \mathrm{Nb}$ ratios $>1.2$ typical of the $\mathrm{A}_{2}$ subgroup. They display singular REE pattern with nearly similar contents being enriched in LREE with moderately depleted in HREE.

3. The ground gamma-ray measurements of the concerned granites indicated that Gabal Homret El Sawrhiya and associated pegmatites exhibit the highest radioactivity in the study area. Such granite sharing common mineralogical and geochemical characteristics with the U-bearing granite in Egypt. It 
Petrography, geochemistry and radioactivity of alkaline A- type granites

has high amounts of radioactive inclusions and high abundances of zircon, which elevated the background values of $U$ and Th. Moreover, it displays different shapes of post-magmatic hydrothermal alterations of which are indicative of uranium deposition.

\section{REFERENCES}

Abdel Hadi, A. M. (2006): Geological setting and radio-elements distribution in G. El Resha-Wadi Atrash area, North Eastern Desert, Egypt. M. Sc. Thesis, Fac. Sci., Benha Univ., 294pp

Abdel Hamid A. A. (2013): Mineralogical and geochemical studies of the Uranium-Bearing Granites, G. Abu Harba area, North Eastern Desert, Egypt. Ph. D. Theis, Fac. Sci., Benha Univ, 173pp

Abu El Leil I A (1980): Geology, petrography and geochemistry of some granitic rocks in the northern part of the basement complex, Egypt. Ph. D. Thesis, Fac. Sci., Al-Azhar Univ., Cairo, 294pp

Ali K A, Moghazi A-K M, Maurice A E, Omar S A, Wang Q, Wilde S A, Moussa E M, Manton W I, Stern R J (2012): Composition, age, and origin of the $\sim 620$ Ma Humr Akarim and Humrat Mukbid A-type granites: no evidence for pre-Neoproterozoic basement in the Eastern Desert, Egypt. Int J Earth Sci (Geol Rundsch) 101, 1705-1722.

Bentor Y (1985): The crustal evolution of the Arabian-Nubian Massif with special reference to the Sinai Peninsula. Precambr Res 28, 1-74.

Bonin B. (1990): From orogenic to anorogenic settings: evolution of granitoid suites after a major orogenesis. Geol J 25, 261-270.

Bonin B (2007): A-type granites and related rocks: evolution of a concept, problems and prospects. Lithos 97, 1-29.

Collins W J, Beams S D, White A J R, Chappell B W (1982): Nature and origin of A-type granites with particular reference to Southeastern Australia. Contrib Mineral Petrol 80, 189-200.

Cuney M (2003): Uranium potential of Eastern Desert granite, Egypt. Unpublished Internal Report, Nuclear Materials Authority, Cairo, Egypt.

De La Roche H, Leterrier J, Grand Claude P, Marchal M (1980): A classification of volcanic and plutonic rocks using $\mathrm{R}_{1}-\mathrm{R}_{2}$ diagrams and major element analyses - its relationships with current nomenclature. Chem Geol 29: 183-210.

Eby G N (1990): The A-type granitoids: a review of their occurrence and chemical characteristics and speculations on their petrogenesis. Lithos 26, 115-134.

Eby G N (1992): Chemical subdivision of the A-type granitoids: petrogenetic and tectonic implications. Geology 20, 641-644.

El Feky, M. G. (1996): Geochemical and mineralogical studies of Umm El Guruf area, North Eastern Desert, Egypt. M. Sc Thesis, Fac Sci, Cairo Univ, Egypt, 222pp

El-Sayed M M, Shalaby, M H, Hassanen M A (2003): Petrological and geochemical constraints on the tectonomagmatic evolution of the late Neoproterozoic granitoid suites in the Gattar area, North Eastern Desert, Egypt. Jb Miner Abh J Miner Geochem 178, 239-275.

Eyal M, Litvinovsky B, Jahn B M, Zanvilevich A, Katzir Y. (2010): Origin and evolution of postcollisional magmatism: Coeval Neoproterozoic calc-alkaline and alkaline suites of the Sinai Peninsula. Chem. Geol., 269,153-179.

Ewart, A (1982): The mineralogy and petrology of tertiary-recent orogenic volcanic rocks, with special reference to the andesitic-basaltic compositional range. In: Thorpe R S (Ed), Andesites: Orogenic Andesites and Related Rocks. Wiley, New York, 25-95.

Flanagan, F. J. (1976): Compilation of data on USGS standards. In: Flanagan F J (Ed) Descriptions and analyses of eight new USGS rock standards. USGS professional paper 840, 131- 183.

Frost, B. R., Barnes C G, Collins W J, Arculus R J, Ellis D J, Frost C D (2001): A Geochemical Classification for Granitic Rocks. J Petrol 42, 2033-2048.

Herrmann, A G (1970): Yttrium and lanthanides. In: K H Wedepohl (ed), Handbook of geochemistry, II/2, Springer-Verlage, Berline, 39-57.

Jarrar, G. H., Wachendorf H, Saffarini G (1992): A late Proterozoic bimodal volcanic/subvolcanic suite from Wadi Araba, Southwest Jordan. Precamb. Res., 56, 51-72. 


\section{Abdel Hamid, A. A.}

Jarrar, G. H., Manton W I, Stern R J, Zachmann D (2008): Late Neoproterozoic A-type granites in the northernmost Arabian-Nubian Shield formed by fractionation of basaltic melts. Chem. Erde., 68, 295312.

Kretz, R. (1983): Symbols for rock forming minerals. Amer. Miner., 68, 277-279.

Liégeois J-P, Black R (1987): Alkaline magmatism subsequent to collision in the Pan-African belt of the Adrar des Iforas. In: Fitton J G, Upton, B G J (Eds), Alkaline Igneous Rocks. Geol Soc Spec Publ 30, 381-401.

Maniar, P. D., Piccoli, P. M. (1989): Tectonic discrimination of granitoids. Geol Soc Am Bull 101, 635643.

Pearce, J. A. (1996): Sources and settings of granitic rocks. Episodes 19, 120-125.

Pearce J. A., Harris N B W, Tindle A G (1984): Trace element discrimination diagrams for the tectonic interpretation of granitic rocks. J Petrol 25, 959-983.

Rogers J. J. W., Greenberg J. K. (1990): Late-orogenic, post-orogenic, and anorogenic granites: distinction by major-element and trace-element chemistry and possible origin. J. Geol., 98, 291- 309.

Roz M. E. (2001): Geology and uranium potentialities in G. Abu Harba environs, North Eastern Desert, Egypt. PhD Thesis, Fac Sci, Cairo University, 264pp

Stern R. J., Gottfried D. (1986): Petrogenesis of a Late Precambrian (575-600Ma) bimodal Suite in northeast Africa. Contrib Mineral Petrol 92, 492-501.

Stern R J, Gottfried D (1989): Discussion of the paper "Late Pan-African magmatism and crustal development in northeastern Egypt". Geol J 24, 371-374.

Sun S. S., McDonough W. F. (1989): Chemical and isotopic systematic of oceanic basalts: implications for mantle composition and processes. In: Saunders A D, Norry M J (Eds), Magmatism in the Ocean Basins. J. Geol. Soc. London, 42, 313- 345.

Sylvester P. J. (1989): Post-collisional alkaline granites. J Geol 97, 261-280.

Taylor, S. R., McLennan S. M. (1985): the continental crust: its composition and evolution: Black-well, Oxford, 312pp

Van Schmuss, W. R. (1995): Natural radioactivity of the crust and mantle. Global earth physics-a handbook on physical constants. AGU Reference Shelf 1, 283-291.

Vladykin, N. V., Alymova, N.V., Perfil'ev, V. V. (2016): Geochemical Features of Rare-Metal Granites of the Zashikhinsky Massif, East Sayan. Petrology 24, 512-525.

Whalen, J. B., Currie, K. L., Chappell, B. W. (1987): A-type granites: geochemical characteristics, discrimination and petrogenesis. Contrib Mineral Petrol 95, 407-419.

Whalen, J. B., Jenner, G. A., Longstaffe, F. J., Robert F., Gariepy, C. (1996): Geochemical and isotopic (O, $\mathrm{Nd}, \mathrm{Pb}$ and $\mathrm{Sr}$ ) constraints on A-type granite: petrogenesis based on the Topsails igneous suite, Newfoundland Appalachians. J. Petrol., 37, 1463- 1489.

Zhang, G., Hu, R., Bi, X., Feng, H., Shang P., Tian, J. (2006): REE Geochemical Characteristics of the No. 302 Uranium Deposit in Northern Guangdong, South China. Chin J Geochem 26, 425-433. 
Petrography, geochemistry and radioactivity of alkaline A- type granites

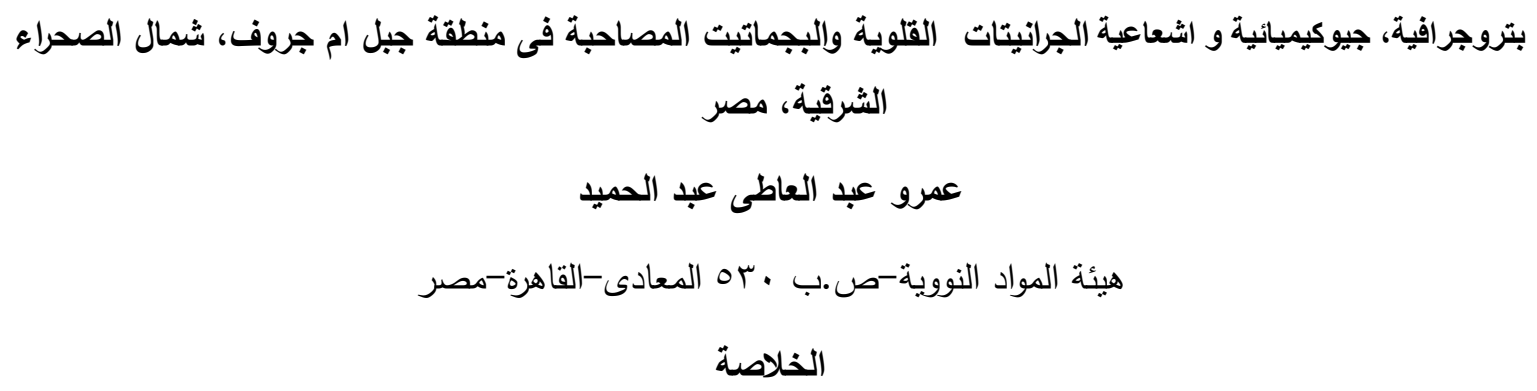

